\title{
The Role of Good Faith and Fair Dealing in Contract Law: A Hair-Shirt Philosophy?
}

\author{
The Hon. Mr Fustice Steyn ${ }^{\star}$
}

The aim of any mature system of contract law must be to promote the observance of good faith and fair dealing in the conclusion and performance of contracts. The first imperative of good faith and fair dealing is that contracts ought to be upheld. But there is another theme of good faith and fair dealing: the reasonable expectations of honest men must be protected. It occasionally requires that the law should treat contractual obligations as defeasible or that a discretionary remedy should be denied. In these broad terms the common law and the civil law have a shared view of the aim of the law of contract.

It is in the matter of high technique that the jurisprudence of common law and civil law countries sharply differ. The level of generality of legal rules lies at the heart of the difference. English law favours empirical and concrete solutions; the civil law proceeds deductively from broad first principles. This difference in approach extends to statute law. In England the prevailing legislative technique seeks to provide detailed and concrete regulation. In civil law countries the legislative technique of stating broad principles still has great appeal. In New Zealand Shipping Co. Ltd v. A. M. Satherwaite $\mathcal{E}$ Co. Ltd., ${ }^{1}$ Lord Wilberforce characterised English contract law as follows: ${ }^{2}$

"English law, having committed itself to a rather technical and schematic doctrine of contract, in application takes a rather practical approach, often at the cost of forcing the facts to fit uneasily into the marked slots of offer, acceptance and consideration."

In Interfoto Library Ltd. v. Stilleto Ltd., ${ }^{3}$ Lord Justice Bingham drew attention to the fact that in many civil law systems the law of contract recognizes and enforces an overriding principle that in making and carrying out contracts parties should

* The Royal Bank of Scotland Lecture 1991, Oxford, published by arrangement with Mr Justice Steyn and the Royal Bank of Scotland.

1. [1975] Q. B. 154.

2. At p. 167 .

3. [1989] 1 Q. B. 433. 
act in good faith. He pointed out that it means a great deal more than that parties ought not to deceive each other. He added: ${ }^{4}$

"English law has, characteristically, committed itself to no such overriding principle but has developed solutions in response to demonstrated problems of unfairness."

In my view Lord Justice Bingham has encapsulated the distinctive features of the two great progenitors of national legal systems, the common law and the civil law.

This difference in technique between the common law and the civil law is linked with a fundamental difference in philosophical approach between the common law and the civil law. The common law requires consideration for the existence of an enforceable contract. The civil law requires only subjective consensus ad idem. The approach of English law to the formation of a contract is largely objective. In civil law regimes it is largely subjective. In England there is an objective theory of the interpretation of contracts, with a rigid exclusion of evidence of prior negotiations and subsequent conduct as an aid to interpretation. In civil law jurisdictions the approach is more subjective, and evidence of prior negotiations and subsequent conduct is treated as part of the logically probative material. Throughout the web of English contract law the criterion of the reasonable man's response predominates. In the civil law greater account is taken of subjective factors. This emphasis of English law on an objective approach to contractual issues tends to make England somewhat infertile soil for the development of a generalized duty of good faith in the performance of contracts.

It is interesting to reflect how greatly commercial cases, and in particular international trade cases, have contributed to the shaping of the distinctive features of our law of contract. The perceived needs of commerce have been decisive. The dominant view has been that concrete regulation best serves the needs of commerce. The vigour of this view has spilled over into the field of commercial arbitration. Generally speaking, civil law countries allow parties to an arbitration agreement to stipulate that the arbitrator shall settle their differences ex aequo et bono or by amiable composition. Indeed, the Model Law of Arbitration, which was published by the United Nations Commission on International Trade Law (UNCITRAL) in 1985, expressly authorizes such methods of dispute resolution if the parties have so agreed. ${ }^{5}$ To this day the orthodox view in England is that all clauses giving an arbitrator the power to decide in accordance with good conscience rather than legal rules are devoid of legal effect. Significantly, this restriction on the freedom of parties is said to rest on English public policy. Enough has been said to demonstrate a certain distrust of the aequum et bonum in England. 
It is no part of my thesis that the civil law of contract is a more logical system than the common law. Like any other system the common law has flaws. But it is by and large a coherent and logical system. It is, however, undoubtedly a system that favours concrete rather than general solutions. This can be illustrated by a few practical examples. In English law the doctrine of rectification had to be developed to deal with cases where an integrated written contract inaccurately reflects the true agreement of the parties. No such doctrine is needed in civil law jurisdictions because it would be contrary to good faith for a party to put forward as accurate a document which does not reflect the true agreement of the parties. The second example relates to the implication of contractual terms. There is a popular misconception that it is particularly difficult in English law to imply terms in a contract. Compared to the civil law, English law shows a considerable hospitality to implied terms. In civil law countries the existence of a generalized duty of good faith in the performance of contracts reduces the need for the implication of terms. In the absence of a doctrine of good faith English law has to resort to the implication of terms by reason of the nature of the contract (e.g., an implied duty to cooperate where the contract cannot be performed without cooperation, as in MacKay v. Dick) ${ }^{6}$ or by reason of special circumstances of a particular contract. The third example is the burgeoning field of estoppel by representation and by convention. In the absence of a generalised duty of good faith the specific and concrete rules of estoppel are needed to deal with demonstrated problems of unfairness.

I do not intend to examine the subject of my lecture historically. My purpose is simply to consider the question whether England has anything to learn from jurisdictions where, in the field of contract law, duties of good faith and fair dealing are of general application. Traditionally, English lawyers have been unreceptive to such ideas. The title of this lecture echoes the remarks of Lord Templeman in Banque Financiere v. Westgate Insurance Co. ${ }^{7}$ a case in the House of Lords in which my flirtation with notions of fair dealing, in a very different context, was conclusively and decisively rejected by the House of Lords. Lord Templeman said: 8

"A professional should wear a halo but need not wear a hair shirt."

It is probably right to say that most English lawyers still adopt an equally jaundiced view of notions of good faith and fair dealing.

On the other hand, there are winds of change which may produce a climate more receptive to notions of good faith and fair dealing in England. Under the influence of civilian traditions the United States Uniform Commercial Code, ${ }^{9}$ and the

6. (1881) 6 App. Cas. 251.

7. [1990] 3 W.L.R. 364.

8. At p. 374 .

9. S1-203. 
Restatement of Contracts, Second, ${ }^{10}$ now explicitly provide that parties are obliged to observe good faith in the performance and enforcement of a contract. The United States has adopted a synthesis of common law and civil law traditions. Distinguished commentators have also pointed out that in Australia and New Zealand notions of good faith and fair dealing are gaining ground. ${ }^{11}$ In the Australian High Court is has been stated that the rationale of estoppel is good conscience and fair dealing. ${ }^{12}$

But there are also internal signs that English contract law is not to be regarded as set in tablets of stone dating from the time of Lord Eldon. The doctrine of consideration has played a powerful role in the development of English contract law. In England consideration is not under siege. It has not been qualified out of existence. On the other hand, in the practice of the courts, particularly in commercial cases, it has receded in importance. It may be negative anecdotal evidence but I have no recollection of any claim in the Commercial Court failing for lack of consideration in recent years. Privity of contract used to be regarded as the cornerstone of the law of contract. The notion of an enforceable stipulatio alteri was a heresy to traditionalists. Yet now we find that the Law Commission is actively investigating the question whether the privity rule should be maintained in its present rigid form. Earlier in this lecture I referred to general observations of Lord Justice Bingham in the Interfoto case. It is also instructive to consider his approach to the decision to be made in that case. The issue before the Court was the application of the doctrine of notice of standard form contractual conditions. Lord Justice Bingham held: ${ }^{13}$

'The tendency of the English authorities has, I think, been to look at the nature of the transaction in question and the character of the parties to it, to consider what notice the party alleged to be bound was given of the particular condition said to bind him; and to resolve whether in all the circumstances it is fair to hold him bound by the condition in question. This may yield a result not very different from the civil law principle of good faith, at any rate so far as the formation of the contract is concerned."

Today, there is at our universities a keen awareness of the fact that the law of contract, tort and restitution ought to be seen as part of a coherent law of obligations: each knitting into the other and influencing the other. The recent decision of the House of Lords in Murphy v. Brentwood District Councill' has heralded a remarkable contraction in the scope of the law of tort. No doubt the

10. S. 205.

11. H. K. Lucke, "Good Faith and Contractual Performance", in P. D. Finn (ed.), Essays on Contract (1986), pp. 18-21; P. D. Finn, "Commerce, the Common Law and Morality", Melbourne University L.R., 17 (1989), p. 87.

12. Walton's Stores (Interstate) Ltd. v. Maher (1988) 62 A.L.J.R. 110, at p. 129.

13. Supra n. 3, at p. 455 B-C.

14. [1990] 3 W.L.R. 414. 
pendulum will swing again. For the present, however, the policy of incrementalism rather than high principle reigns. But it is interesting to speculate whether the effect of the contraction of the law of tort will result in an extension of contractual techniques. Possibly we will hear more about collateral contracts in the next few years.

There are international portents of change in relation to notions of good faith and fair dealing. On 11 April 1980 the representatives of 62 states (including representatives of the United Kingdom) approved the United Nations Convention on Contracts for the International Sale of Goods. The Vienna Sales Convention, as it is commonly called, required ratification by at least 10 states. It duly came into force on 1 January 1988. By the end of April 1991, 30 states had ratified the Vienna Sales Convention. Seven states are engaged in the process of ratification. It is believed that the number of ratifications may increase to 50 in the next two years. Within the European Economic Community, France, Italy and Germany have ratified the convention. In the common law family of states the United States and Australia have ratified the convention. Clearly, the international market place is voting for the convention. No international convention will ever completely satisfy all countries. But the text of the Vienna Sales Convention represents a satisfactory compromise between contrasting points of view. ${ }^{15}$ Hopefully, there will shortly be a ministerial announcement that the United Kingdom will ratify the convention. If the will to ratify this convention now is absent, our businessmen will be placed at a disadvantage in international commerce. The Vienna Sales Convention bears the badge of neutrality, and it will prove popular among businessmen worldwide. If the United Kingdom does not ratify the convention now, commercial realities will compel ratification later. What, you may ask, does this have to do with my paper? The answer is that it underlines three points which are worth making. In the first place the convention demonstrates convincingly that in sales law the principles of the civil law and the common law can be blended into a coherent text. Secondly, if this country is to play a positive and influential role in the harmonization of international trade law, an insular attachment to the unsullied purity of the common law is not the best way forward. Thirdly, Article 7(1) provides:

"In the interpretation of this convention, regard is to be had to its international character and to the need to promote uniformity in its application and the observance of good faith in international trade."

Here one has a classic compromise which enabled the experience of the common law and the civil law to be blended into a generally acceptable international convention. The convention does not create a duty to observe good faith in the conclusion and performance of contracts. Article 7(1) only requires the observance

15. B. Nicholas, "The Vienna Convention on International Sales Law", (1989) 105 L.Q.R. 201. 
of good faith in the interpretation of the convention itself. Nevertheless, if England ratifies the convention, English lawyers and judges will become used to employing the criterion of good faith in the wide process of interpretation of the convention.

The impact of the EEC on English contract law is a matter for a future generation of legal historians. Provisionally, it is my impression that the technique of the civil law is bound to play a major role in the decision making processes of EEC institutions, and that it is unlikely that the traditional technique of English contract law will remain unaffected. There is opportunity here for only one example. In September 1990, the European Commission published a Proposed Directive for submission to the Council of the European Communities. The purpose of the Proposed Directive is to facilitate the establishment of a single internal market by December 1992 by ensuring harmonized consumer protection laws in EEC countries. It applies to every contract between a consumer and a party acting in the course of trade, business or profession. It prohibits the use of unfair terms, and renders such terms void if used in contravention of the prohibition. The Proposed Directive is not limited to exception and limitation clauses: it extends to all contractual terms. It spells out that a term is unfair, inter alia, if:

"it is incompatible with the requirements of good faith."

If the Proposed Directive becomes law, it will be incumbent on the United Kingdom to give effect to its terms. The criterion of good faith will then come to play an important policing role over contractual terms in our consumer law. On the other hand, it is important to note that the Proposed Directive does not create a duty of good faith in the performance of contracts. Prohibiting unfair terms, and creating a positive duty of good faith in the performance of contracts, are very different things.

The philosophy of caveat emptor rather than notions of good faith and fair dealing has dominated English contract law. In Bell v. Lever Bros. ${ }^{16}$ it was stated to be a principle of universal validity. Yet the notions of good faith and fair dealing have left some imprint on English contract law. Apart from special fiduciary relationships, contracts of insurance, suretyship, salvage and partnership are categorized as contracts of the utmost good faith. On the other hand, the scope of the duty of disclosure under a contract of insurance is very different from the scope of the duty of disclosure under contracts of suretyship, salvage and partnership. Later I will turn briefly to insurance contracts. Rules of equity regarding contractual penalties, unconscionable bargains and the limited remedy of relief from forfeiture also provide a refrain reminiscent of good faith notions. A classic instance of the notions of good faith and fair dealing prevailing over caveat emptor is provided by the rule that a party is not entitled to "snap up" an offer which he 
knows to have been made under a mistake. ${ }^{17}$ Sometimes duties of good faith are implied in particular contracts. In every contract of employment there is a term that the employer will not, without reasonable and proper cause, conduct himself in a manner calculated to destroy or seriously damage the relationship of confidence between employer and employee. ${ }^{18}$ This term has been held to be an implied obligation of good faith. ${ }^{19}$ Bearing in mind that an implied term must be clear and workable, the implication of an implied term of good faith in employment contracts must count as some acknowledgement of the utility of the concept of good faith in English contract law. Another thread is provided by cases where the contract expressly provides that the question whether a particular condition is fulfilled will depend on the unilateral approval of one of the parties. The interpretation of such a clause, depending on the language and context, will almost invariably be either that the decision making party must have reasonable grounds for his decision or that he need only act in good faith. ${ }^{20}$ This is an example of English courts introducing the concept of good faith in a contractual context by a process of construction.

Our legislature has also on occasions adopted the technique of setting statutory standards of fair dealing. Three examples will be sufficient. A defence of fair dealing has existed under the Copyright Acts of 1911, 1956 and 1988. Until 1988 the defence applied only to literary, dramatic or musical copyright. In 1988 that defence was extended to broadcasts. Then there is the Unfair Contract Terms Act 1977. Although the Act does not expressly use the terminology of good faith and fair dealing, nevertheless it adopts a similar technique by requiring certain contractual terms to run the gauntlet of a criterion of reasonableness. By and large, however, the scope of the Act is restricted to exception and limitation clauses. Another illustration is to be found in the Consumer Credit Act 1974. It provides that if the Court finds a credit bargain extortionate it may reopen the credit agreement so as to do justice between the parties. It is expressly provided that a credit bargain is extortionate if it grossly contravenes ordinary principles of fair dealing. I do not, of course, suggest that by using the analogy of statutes judges may create new legal rights and obligations. But often judges have to choose between equally feasible solutions, and statutes can then legitimately be invoked as demonstrating the good sense or workability of a particular solution.

Taking stock of the position, my conclusion is that good faith and fair dealing have so far played a limited role in English contract law. But there are signs that the English legal culture may become (or may have to become) more receptive to such notions.

How much difference does it make whether a legal system is based on a patchwork of concrete legal rules, or uses the technique of an generalised duty of

17. Hartog v. Colin and Shields [1939] 3 All E.R. 566.

18. Woods (1981) IRL.R. 347.

19. Imperial Group Pension Trust Ltd. v. Imperial Tobacco Ltd. [1991] 2 All E.R. 597, at p. 606b.

20. Niarchos (London) Ltd. v. Shell Tankers [1961] 2 Lloyd's L.R. 496. 
good faith? In a seminal article published in 1956, Professor Raphael Powell stated his provisional answer as follows. ${ }^{21}$ First, he said that quite often the foreign court, using the medium of a rule requiring good faith, arrives at the same conclusion as an English Court which has used another rule or a more roundabout route. Relying on such limited practical experience as I have in the resolution of international trade disputes, governed by different laws, I would change the emphasis slightly by saying that an identical result by a different route is the general pattern. Secondly, Professor Powell said that in a number of cases a rule requiring good faith has enabled the foreign court to adjust relations between the parties more equitably than an English court in similar circumstances. My impression is that this proposition is correct to this day. But any judge's unconcious bias in favour of the justice and the merits of the case tends to reduce the incidence of different results.

Having indulged in too many generalities, it is now necessary to consider a case where one would expect a general duty of good faith in the performance of a contract to generate fair subsidiary rules. I select the example of an insurance contract which in the theory of English law imposes duties of the utmost good faith on both parties to the contract. In Carter v. Boehm, ${ }^{22}$ decided in 1766 by Lord Mansfield, it was ruled that the uberrima fides principle, as it is sometimes called, imposes reciprocal duties of good faith on the insured and insurer. Lord Mansfield said that this principle extends to all contracts. This view was soon rejected but in relation to contracts of insurance the principle of $u$ berrima fides has survived. My reason for selecting this example is twofold. First the contract of insurance is of great importance to commercial users and consumers alike. Secondly, this example will illustrate that what matters is not whether a contract is characterised as one giving rise to duties of good faith but whether the reality matches the nomenclature.

The rules governing non-disclosure under a contract of insurance sometimes compel a court to reach unfair results. ${ }^{23} \mathrm{~A}$ minor and innocent non-disclosure may entitle the insurer to avoid. In Container Transport Inc. v. Oceanus Mutual Underwriting Association (Bermuda) Ltd., ${ }^{24}$ the Court of Appeal stated the law in terms which are starkly at variance with notions of good faith. First, the Court of Appeal ruled that in relation to the materiality of the matter not disclosed the only relevant yardstick was the probable reaction of a prudent insurer if it had been disclosed: it is irrelevant what the actual insurer's reaction would have been. Secondly, the Court of Appeal ruled that the proper test as to materiality is not whether the matter in question would have influenced the judgment of a prudent insurer in deciding whether to take the risk or in fixing the premium. The question

21. "Good faith in Contracts", [1956] C.L.P. 16.

22. 3 Burr, 1905.

23. See R. A. Hasson, "The Doctrine of Uberrima Fides in Insurance Law - a Critical Evaluation"? (1969) 32 M.L.R. 615.

24. [1984] 1 Lloyd's L.Rं. 476. 
is simply whether the matter not disclosed would have been taken into account by the underwriter in his decision making process. Since the Container Transport case related to marine insurance, the proper construction of the Marine Insurance Act 1906 played a major role in the reasoning of the court. But the Act, although not exhaustive, was a restatement of the common law. And, like cases ought to be decided alike. This decision is therefore equally applicable outside marine insurance law.

While the correctness of the Container Transport decision is not in issue, one can legitimately ask whether the law as stated in this case is satisfactory. It is difficult to understand why an underwriter should be able to avoid a contract for nondisclosure, when he would have written the risk anyway. If he would have chosen not to act as a prudent underwriter would have done, because he was seeking to create a new book of business, why should he be able to avoid? Moreover, how can avoidance on the grounds of a non-disclosure, which was causally irrelevant as far as the actual underwriter is concerned, be squared with the proposition that the parties owe each other reciprocal duties of the utmost good faith? Under the general law of misrepresentation proof of actual inducement is necessary. Why should an insured's position under a contract of the utmost good faith be less favourable?

The second point is also important. In the Container Transport case the trial judge had held that the test of materiality is whether the non-disclosure would have influenced the judgment of a prudent underwriter in accepting the risk or fixing the terms. As a result of the decision in the Court of Appeal the law is now that it is sufficient if the underwriter would have taken the matter into account albeit that he would thereafter have dismissed it from his mind as unimportant. This statement of the law is not in accord with the general law regarding misrepresentation. A party who seeks to avoid a contract on the ground of misrepresentation must show on a balance of probabilities that he was induced. It is easy for an insurer, upon rummaging through the documents an insured has disclosed upon discovery, to find grounds for raising defences of non-disclosure. Is this rule fair? Assume a fire insurance where a shopkeeper failed to disclose a small fire 10 years ago since when the shopkeeper introduced additional fire precautions. Conceivably, the evidence might show that if the matter had been disclosed a prudent underwriter would have written the risk on exactly the same terms. But it will in practice be easy to find an underwriter to testify that he would have taken the earlier fire into account. Does it accord with good faith and fair dealing, that the insurer should be able to avoid on such flimsy grounds?

Accepting the law as stated in Container Transport to be correct, it seems to me that the rules regarding non-disclosure under a contract of insurance are unfairly tilted in favour of the insurers. The only justification for this state of law is a premise that makes the insurers the judges in commercial causes in which they stand to lose money. The traditional argument is: insurers act responsibly and would only rely on a technical non-disclosure if there is good reason to suspect 
deliberate misconduct by the insured. It is a specious argument. This part of English insurance law is not easy to reconcile with duties of good faith and fair dealing.

It is also of some interest to consider the policy of our legislature in relation to insurance contracts. The insurance policies currently in use in England contain many unfair conditions and exceptions. Yet the Unfair Contract Terms Act 1977 provides that such contracts are wholly excluded from the scope of the Act. In this respect our Act is different from corresponding legislation in some other E.E.C. countries. The fact that the contract is a contract of the utmost good faith ought surely to be an incentive to prohibit, or control, unfair conditions and exceptions in contracts of insurance. Why are contracts of insurance excluded from the scope of this legislation? No ground of public interest suggests itself. There is only one answer: the astonishing strength of the insurance lobby secured the exemption.

Returning now to the question in the title of this paper, my answer is that good faith and fair dealing is in no sense a hair shirt philosophy. On the contrary, it has been demonstrated in the hard school of litigation and international commercial arbitration to be a perfectly workable and sensible technique for the imposition of legal duties in many legal systems, and in parts of our own system. Undoubtedly, contract law should strive to attain certainty of rights and predictability of results. But I regard as unproven the assertion that the pragmatic approach of our law necessarily leads to greater certainty and predictability than the more general methods of the civil law. But there is no need to abandon our legal heritage. Our methods have by and large served us tolerably well. Moreover, I am not persuaded that generalised duties of good faith are useful across the spectrum of contractual relations. There are so many varieties of contract. In some contexts good faith and fair dealing have no significant role to play. Such is the case, for example, in many commercial contracts where one is not concerned with fault but simply with an allocation of the risks of a particular undertaking or enterprise. ${ }^{25}$ On the other hand, as our legal culture becomes more familiar with notions of good faith and fair dealing, it may be that in some areas there will be greater scope for using principles of good faith and fair dealing. Here I particularly have in mind consumer law. We live in a consumer society of mass production, distribution and consumption in which the nineteenth century premise of freedom of negotiation is a myth. But even in this field there may be a powerful case for the law to be developed by using the traditional techniques of the common law. My rather lame verdict is that there is no one self-evidently right answer on this point.

But I do firmly believe that if principles of good faith and fair dealing are to gain wider acceptance in consumer law, it will be important not to give to such principles too abstract a moral content. While a definition of good faith and fair dealing is impossible, it seems to me that the law ought not to set its sights too high. 
These notions ought to reflect not the response of a moral philosopher but the responses and usages of ordinary right thinking people. But I would willingly forego such a development, provided that in using the high technique of common law the closest attention is paid to the purpose of the law of contract, i.e., to promote good faith and fair dealing. After all, it is right that academic lawyers, practitioners and judges should constantly consider whether rules of law under consideration serve the purpose which led to their formation. Or, putting it more simply, we must never lose sight of Lord Reid's observation in Cartledge v. $E$. fopling $\mathcal{E}$ Sons $L t d$. that "The common law ought never to produce a wholly unreasonable result ...".26

Nothing is more important than that the next generation of lawyers should approach the activities of Parliament, and the decisions of judges at every level with open-minded scepticism. Vigorous criticism is one of the great shaping forces of the common law. And we must never underestimate the continued capacity of the common law for disciplined growth in accordance with its own traditions. ${ }^{27}$

27. Mr J. Beatson, a Law Commissioner, read a draft of this lecture and made a number of suggestions which I have incorporated in the final text. The flaws in it are entirely my responsibility. 